Original research article

\title{
Selected indicators related to smoking incidence in pregnant women in the Czech Republic
}

\author{
Radka Wilhelmová ${ }^{1 *}$, Liana Greiffeneggová ${ }^{1,2}$ \\ ${ }^{1}$ Masaryk University, Faculty of Medicine, Department of Midwifery and Paramedics, Brno, Czech Republic \\ ${ }^{2}$ Masaryk University, Faculty of Medicine, Department of Public Health, Brno, Czech Republic
}

\begin{abstract}
Introduction: Both pre-conception and especially a mother's (parents') prenatal risk habits play a very significant role in the etiology of baby ontogeny abnormalities and health disorders. These abnormalities and disorders can manifest themselves immediately or in longterm latency. The behavior of future mothers is affected with their knowledge, which forms the basis of women's everyday habits. This is an expression of their health literacy and psychosocial factors. This can be positively influenced by care providers (midwives) within prenatal counseling or courses, preferably before the conception.

Aim: The aim of the survey was to find out the current level of health literacy in the field of women's smoking in connection with their pregnancy, and the factors which affect it the most.

Materials and methods: The questionnaire survey and evaluation of selected anthropometric parameters in women after birth in selected bed-care facilities in Bohemia and Moravia were used for the study (research). Statistical analyses was carried out by Pearson's test $\chi^{2}$ (chi-square) and Anova test on significance level 0.05.

Results: It was found that in spite of relatively good awareness, smoking is a widespread habit among the population of potential mothers and is connected to education level and smoking in a woman's family history. Some women (30\%) quit smoking when they decide to get pregnant or during pregnancy. Some women (10\%) do not give up the habit despite being aware of the risk to both mothers' and babies' health.

Conclusions: It is clear that the prevention and elimination of the risk behavior of pregnant women, in our case smoking, still shows considerable insufficiencies. An important part of the effective prevention of fetal harm and future development of the child, not only in the context of prenatal care, is health literacy, which can be improved through prenatal courses and counseling led by a midwife.
\end{abstract}

Keywords: Health literacy; Influence factors; Smoking; Pregnancy; Prenatal courses; Risks

\section{Introduction}

As expectant parents and prenatal care providers, we significantly influence the health and lives of our children. Sources focusing on epigenetic mechanisms show prenatal and preconception influencing factors and inform about the fact that environment and reactions to it run our gene activity (Lipton, 2011). The physiological level of reproductive health is influenced by a couple's health literacy created by a sufficient amount of knowledge as a part of everyday skills. Insufficient health literacy is a cause of risky behavior with a negative effect on health, and from the long-term view it has a trans-generational impact (Baker, 2010). The question is how much it can be influenced by today's prenatal care. Prenatal care has a long tradition, the result of which, as well as the main evaluation criteria, is a low prenatal mortality. It provides a large amount of secondary and tertiary prevention, but in comparison with other countries it remains insufficient in cases of the preven- tion of risky behavior in women before and during pregnancy (Harville et al., 2010; Holčík, 2010). Foreign experience shows that a comprehensively designed model of care has to include all services positively influencing health and wellness of a woman and a child. One of the evaluation criterion should be the level of health literacy of parents, from the point of view of newborn evaluation, not only gestational age and somatic expressions, but also optimal brain development and its future health (Berglund, 1999; Iams et al., 2008).

The brain is the main target organ of fetal programming. Toxins from smoking, alcohol and other drugs, chronic illnesses, long-term use of medicines and persistent stress lead to increased loss of neurons (Mulder et al., 2002; Welberg and Seckl, 2001). Risky behavior of parents represents a significant risk factor for a model of the future child's habits. That is why primary prevention should be focused on parents in the period before conception, and at the latest in the early developmental stage of an individual in the uterus. Midwives could significantly eliminate risks. Primary prevention could

\footnotetext{
* Author for correspondence: Radka Wilhelmová, Masaryk University, Faculty of Medicine, Department of Midwifery and Paramedics, Komenského náměstí 2, 66243 Brno, Czech Republic; e-mail: rwilhelm@med.muni.cz http://doi.org/10.32725/kont.2019.022

Submitted: 2018-07-31 • Accepted: 2019-01-30 • Prepublished online: 2019-04-08 
bring not only good perinatal results in terms of numbers, but also a positive pregnancy experience of women (Hrubá and Žaloudíková, 2009; WHO, 2018).

The intrauterine exposure to drugs causes a lifetime physical and mental handicap in many cases. Chronic hypoxia and hyponutric fetus as a result of smoking habits are one of the most essential and negative developmental conditions that influence epigenetic modification of DNA (Gollwitzer and Marsland, 2015). Changes made by the fetus to adjust to negative intrauterine conditions have a lasting impact on its total metabolism and tissues. Asymmetric growth retardation of the fetus appears as an external manifestation. On the other hand, maternal antioxidants work protectively (Patterson et al., 2010; Paul et al., 2008). Most of the harmful substances from cigarette smoke pass through a placental barrier and slow down metabolism. Nicotine starts a cascade of reactions increasing the level of dopamine. Simultaneously, serotonin activates sympathetic nerves, and adrenal glands with the effect of vasoconstriction, tachycardia and blood pressure increase. It disrupts the dopaminergic and serotonergic system in the central nervous system, which can manifest as behavioral disorders, reducing intellect functions, and causing hyperactivity with attention disorders not only in young age but adult age too (Hrubá, 2007; Kukla et al., 2000; Lillycrop and Burdge, 2012).

The incidence of smoking in the population of some European countries (Sweden, Iceland) is decreasing. Up to now, the situation in the Czech Republic has not been good. One third of the adult population smokes, and there are up to $40 \%$ of smokers in the age range 15-19 years. The percentage of smoking girls and women has been increasing. A higher prevalence and intensity of smoking is found in people from lower social classes. Passive smoking endangers every four out of ten non-smokers. Smoking causes an increased incidence of different chronic illnesses, including allergies or asthma, and brings serious financial consequences for a family as well (ÚZIS ČR, 2012).

Smoking is one of the factors that significantly influences developmental disorders during pregnancy, as well as perinatal mortality as a result of a health condition and social environment factor combination. Premature termination of pregnancy and placental pathology are complications appearing in pregnant smoking women. Consequently, a lower production of breast milk and insufficient child gain increments are found. Passive smoking (second and third hand smoking) causes similar risks. Smoking of mothers has a lasting impact on the reproductive health of the descendants of both sexes (spermatogenesis, production of sex hormones, ovarian functions). Smoking of fathers has a negative impact in the preconception period too - there is an increase in birth defects of children and reproductive disorders (Hackshaw et al., 2011; Hrubá et al., 2013; Malik et al., 2008; Šípek et al., 2012).

Most of the female smokers have bad eating habits connected with malnutrition, resulting in slowed development of the skeletal muscle system, brain development and decreased lung function of the fetus. The risk of delivering low birth weight newborns (<2500 g) has been increasing. Women smokers give birth to newborns who on average weigh 150 to 435 grams less than newborns of women non-smokers. There was found to be a higher gender effect on male fetuses. Disorders of hearing, speaking, behavior and brain functions occur twice as much in children of women smokers, as well as more frequent illnesses of the respiratory system and middle ear infection, childhood tumors and cardiovascular disease. Low birth weight is connected with the risk of chronic diseases in later life (Kataoka et al., 2018; Leonardi-Bee et al., 2008, Lillycrop and Burdge, 2012; Suzuki et al., 2008).

Nicotine metabolism is faster during pregnancy, and for that reason it is more difficult to stop smoking. Women experience greater pressure during pregnancy, with feelings of stress and anxiety. Many gynecologists do not recommend quitting smoking because of the fear of stress reactions. The body's reaction to nicotine intake is equal to stress exposure (in stress but without an external chemical pollutant). Due to pregnancy hormones, some women with lighter nicotine addiction feel aversion to cigarette smoke and they stop smoking. Knowledge of consequences for the fetus and its development is a significant incentive factor. The main obstacle to cessation is usually a partner who is a smoker, as well as tolerant lay and professional public attitude towards smoking. A relapse occurs in up to $80 \%$ of women after giving birth. Smoking and breaking the habit should be consulted at the first prenatal meeting at the latest, and the support should continue in the period after the birth as well. Healthcare interventions should not be focused only on information dealing with negatives for children; holistic health and womens' well-being and a child being part of it should also be considered (Ashford et al., 2010; Ebert et al., 2009; Hrubá, 2011).

\section{Materials and methods}

The surveyed sample was composed of 360 women in their puerperium. This sample represented $1.41 \%$ of $C$ zech women who gave birth within the observed reference period of the year 2012. The set was evaluated in terms of women's age, acquired education, parity, and place of residence (Table 1), as well as visits with the midwife during prenatal courses. Diverse course typology was followed, e.g., short-term being defined as onetime visit course, long-term being defined as several courses on theory, and eventually, theory with hands on practice. The majority of the women (81\%) gave birth vaginally, $19 \%$ had a $\mathrm{C}$-section. Our surveyed set of women corresponded with the findings of the Institute of Health Information and Statistics of the Czech Republic (ÚZIS ČR, 2012) with respect to age, parity, delivery methods and date of the delivery. In comparison to the population, the surveyed set of women was represented by a slightly higher percentage of women with higher education. By carrying out a several stage selection phase the representativeness of the set was secured. The aim of the survey was to determine the current factors that significantly influence the incidence of women smoking during pregnancy. In addition, undesirable phenomena that occur in women in relation to this habit were determined. The selected method was a retrospective anonymous questionnaire survey and subsequent data analysis. The structure of the questionnaire was based on a health support model (Pender, 2011) and a few items from the standardized questionnaire used in a European Longitudinal Study of Pregnancy and Childhood (ELSPAC). Each question block was focused on factors essential for women's health, healthy development of a child during pregnancy and high-risk behavior. The incidence of the smoking habit, including active and passive smoking, and the women's awareness about the risks of such a habit were detected. To determine and evaluate the women's awareness level, an index of awareness composed of 21 questions was created. The value of the index could vary from 0 to 21 . The subjective perception of experiencing stress was evaluated based on a Likert-type scale. The survey was completed with a detection of anthropometric parameters before conception and prepartum, the method of 
delivery and the condition of the newborn including his/her birth weight.

The survey was carried out in selected bed-care health facilities in Bohemia - Central Bohemian Region (1) and South Bohemian Region (1) and in Moravia - Southern Moravian Region (2) and Moravian-Silesian Region (2). Included were both perinatology centers (4) and lower-level hospitals (2). The data were collected by informed health practitioners with complete participant anonymity. The women participating in the survey signed an informed consent form and an agreement with the University Hospital Ethics Committee of the Faculty of Medicine Masaryk University. Statistical evaluation was carried out using the Pearson $\chi^{2}$ (chi-square) test for determining the frequency and the Anova test (analysis of variance) used for testing three or more group means for statistical significance. The statistical significance level was at a value $p=0.05$ or less. Given the size of the sample the selection error was set at $5.4 \%$.

Table 1. Characteristics of the sample - pregnant women

\begin{tabular}{lcc} 
Item & $N$ & $\%$ \\
\hline Number of participants & 360 & 100 \\
\hline Age & \multicolumn{2}{c}{$30.0 \mathrm{y}$} \\
$\quad$ average & \multicolumn{2}{c}{$31.0 \mathrm{y}$} \\
$\quad$ median & & \\
Education & & \\
$\quad$ high school & 145 & 40.3 \\
$\quad$ university & 146 & 40.6 \\
Residence type & & \\
$\quad$ town & 259 & 71.9 \\
$\quad$ village & 101 & 28.1 \\
Gravidity & & \\
$\quad$ primiparous & & \\
$\quad$ secundiparous & 178 & 49.4 \\
$\quad$ multiparous & 146 & 40.6 \\
\hline
\end{tabular}

\section{Results}

The survey did not prove a statistically significant relationship between smoking in women and an occurrence of serious complications in their medical history, during pregnancy or during birth. A significant disparity was affirmed in terms of an incidence of abortion in women's medical history (Table 2). Women with a smoking habit stated abortion more often $(p<$ 0.001). A relationship between a smoking habit in women and a miscarriage recorded in a woman's medical history was not proven $(p=0.767)$.

Table 2. Abortion and a smoking habit in women's medical history (\%)

\begin{tabular}{lcccr} 
& & \multicolumn{2}{c}{ Smoker - yes/no } & \multirow{2}{*}{ Total } \\
\cline { 1 - 3 } & & yes & no & \\
\hline \multirow{2}{*}{ Abortion } & no & 87.3 & 97.2 & 93.2 \\
& yes & 12.7 & 2.8 & 6.8 \\
\hline Total & & 100.0 & 100.0 & 100.0 \\
\hline
\end{tabular}

For the majority of women, awareness about the health risks of active and passive smoking for a woman and a child during pregnancy was satisfactory. The awareness index increased with the level of acquired education (Table 3).

\section{Table 3. Awareness index and acquired education}

\begin{tabular}{lccc} 
Acquired education & $N$ & Mean index value & SD \\
\hline $\begin{array}{l}\text { Lower or upper secondary } \\
\text { education }\end{array}$ & 69 & 15.1 & 5.2 \\
$\begin{array}{l}\text { Upper secondary or post- } \\
\text { secondary education }\end{array}$ & 145 & 17.7 & 3.2 \\
Tertiary education & 146 & 18.5 & 3.1 \\
\hline Total & 360 & 17.5 & 3.8 \\
\hline
\end{tabular}

In spite of being well aware of the risks, $40 \%$ of the surveyed sample stated a smoking habit sometime during their life. Pregnant women categorized themselves as light smokers (1-9 cigarettes per day). During the prenatal phase, $24 \%$ of the fetuses from the sample were exposed to cigarette smoke for a different period. $10 \%$ of the fetuses were exposed to cigarette smoke during pregnancy both passively and actively (Table 4). Smoking in pregnant women (active or passive) was inversely proportional to the level of acquired education $(p<0.001)$ and age $(p<0.001)$. It was common in women with recorded smoking in their family history $(p<0.001)$ to state that they were a smoker or were in a smoky environment on a regular basis (Table 5 and 6). More often (no statistical significance) it was multiparous women who were either a smoker or were in a smoky environment during pregnancy $(p=0.193)$.

There were significantly fewer smokers among women who consciously prepared for their pregnancy $(p=0.009)$. Women who were non-smokers more often attended prenatal courses, especially long-term courses. Women who were smokers tended to attend short-term, one-visit, courses $(p=0.003)$ (Table 7) (Chart 1).

There was a lower percentage of women who were smokers and claimed to be lifetime abstinent ( $5 \%$ vs. $9.5 \%$ of non-smokers). Those women more frequently stated that they drank alcohol even during pregnancy ( $36.4 \%$ vs. $28 \%$ of non-smokers). Women smokers also more often claimed to have experienced stress throughout the pregnancy (23\% vs. $15.4 \%$ non-smokers).

The survey did not prove a significant relationship between smoking in women and complications during pregnancy and birth. However, women who already smoked before conceiving, and women who were exposed to passive smoking during pregnancy, delivered a newborn with low birth weight (less than 2,500 g) more often (Table 8). A low birth weight of a newborn was directly proportional to the education level acquired by a woman. Women who acquired higher education level were also more frequently lifetime non-smokers. It is also necessary to take into account that there were only 21 women who delivered a newborn with a low birth weight, and although this corresponds with the overall statistics for the Czech Republic (ÚZIS ČR, 2012), it could lead to a greater statistical error.

Prenatal courses represent an insufficiently utilized tool for improving health literacy in relation to the prevention of undesirable habits in a high-risk group of women. Long-term courses were more frequently attended by women with a higher education level (also non-smokers) and primiparous women or eventually, by multiparous women who were in close cooperation with a district midwife during their previous pregnancy (Table 9). Women with a lower education level attend prenatal courses less frequently. However, when attending the courses the women show a statistically significantly higher awareness index than women with lower education level who do not attend courses at all. 
Table 4. Smoking in pregnant women in relation to acquired education (\%)

\begin{tabular}{|c|c|c|c|c|}
\hline Women's answers / education & $\begin{array}{c}\text { Lower or upper } \\
\text { secondary (no } \\
\text { graduation) education }\end{array}$ & $\begin{array}{c}\text { Upper secondary } \\
\text { or post-secondary } \\
\text { education }\end{array}$ & $\begin{array}{c}\text { Tertiary } \\
\text { education }\end{array}$ & Total \\
\hline I have never smoked & 20.6 & 59.7 & 78.1 & 59.7 \\
\hline I quit smoking once I decided to conceive & 20.6 & 18.7 & 12.3 & 16.4 \\
\hline I quit smoking during pregnancy & 27.9 & 14.4 & 7.5 & 14.2 \\
\hline I keep smoking even during pregnancy & 23.5 & 2.9 & 0.0 & 5.7 \\
\hline I don't smoke, but I was present in a smoky environment during pregnancy & 7.4 & 4.3 & 2.1 & 4.0 \\
\hline Total & 100.0 & 100.0 & 100.0 & 100.0 \\
\hline
\end{tabular}

\section{Table 5. Smoking in relation to average age of women}

\begin{tabular}{lccc} 
Women's answers & $N$ & Age & SD \\
\hline I have never smoked & 215 & 32.4 & 4.7 \\
I quit smoking once I decided conceive & 59 & 31.8 & 4.0 \\
I quit smoking during pregnancy & 52 & 28.1 & 5.1 \\
I keep smoking even during pregnancy & 20 & 25.7 & 29.9 \\
I don't smoke, but I was present in a smoky environment during pregnancy & 14 & 30.0 & 6.0 \\
\hline Total & 360 & 5.0 &
\end{tabular}

\section{Table 6. Smoking in relation to smoking recorded in a woman's family history (\%)}

\begin{tabular}{|c|c|c|c|}
\hline Women's answers / smoking recorded in a family history & No & Yes & Total \\
\hline I have never smoked & 71.8 & 47.7 & 59.7 \\
\hline I quit smoking once I decided to conceive & 16.4 & 16.5 & 16.4 \\
\hline I quit smoking during pregnancy & 7.3 & 21.0 & 14.2 \\
\hline I keep smoking even during pregnancy & 1.1 & 10.3 & 5.7 \\
\hline I don't smoke, but I was present in a smoky environment during pregnancy & 3.4 & 4,5 & 4.0 \\
\hline Total & 100.0 & 100.0 & 100.0 \\
\hline
\end{tabular}

Table 7. Smoking and preconception planning in women (\%)

\begin{tabular}{|c|c|c|c|c|}
\hline & & \multicolumn{2}{|c|}{ Smoker - yes/no } & \multirow{2}{*}{ Total } \\
\hline & & yes & no & \\
\hline \multirow{2}{*}{ Did you engage in preconception planning? } & yes & 41.5 & 55.9 & 50.1 \\
\hline & no & 58.5 & 44.1 & 49.9 \\
\hline Total & & 100.0 & 100.0 & 100.0 \\
\hline
\end{tabular}

Table 8. Smoking in relation to newborn birth weight (\%)

\begin{tabular}{lcccccrrr} 
& & Never smoked & $\begin{array}{c}\text { Quit smoking } \\
\text { before pregnancy }\end{array}$ & $\begin{array}{c}\text { Quit during } \\
\text { pregnancy }\end{array}$ & $\begin{array}{c}\text { Kept smoking } \\
\text { during } \\
\text { pregnancy }\end{array}$ & Passive smoking & Total \\
\hline $\begin{array}{l}\text { Low birth } \\
\text { weight }\end{array}$ & yes & 5.2 & 8.6 & 6.0 & 5.0 & 7.1 & 9.9 \\
\hline Total & no & 94.8 & 91.4 & 94.0 & 95.0 & 92.9 & 100.0 \\
\hline
\end{tabular}




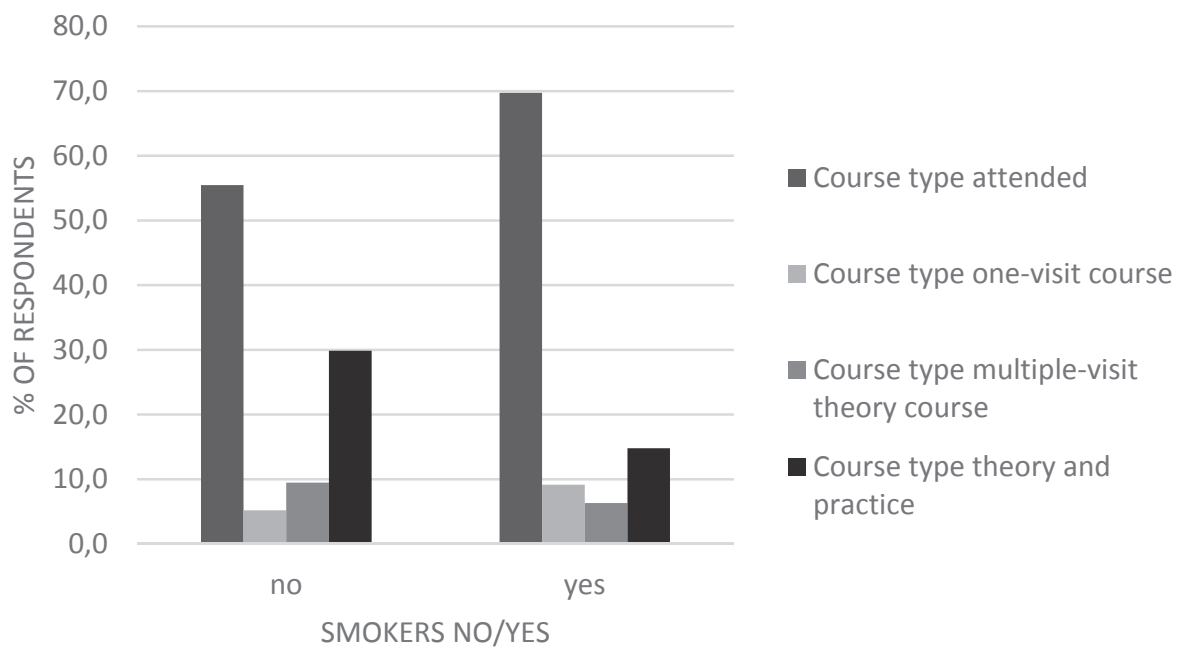

Chart 1. Smoking in women anytime during their life in relation to prenatal course attendance

Table 9. Determinants of prenatal course visitations possibilities of prevention

\begin{tabular}{lcc} 
Item & Determinant & $p<$ \\
\hline & education & $\mathbf{0 . 0 0 0}$ \\
Attendance & parity & $\mathbf{0 . 0 0 0}$ \\
of prenatal & residence & 0.089 \\
course & contact with a midwife during last pregnancy & 0.000 \\
&
\end{tabular}

\section{Discussion}

Both our studies and international studies (e.g. Filion et al., 2011; Hrubá, 2011; Männistö et al., 2016; Schneider and Schütz, 2008) show that about one quarter of pregnant women smoke, and about $10 \%$ of the non-smoking population is exposed to cigarette smoke for more than 1 hour while at home. The percentage of women smoking during pregnancy declines with age; 17 years old and older at $26 \%$, up to 35 years of age 3.8\% (Eurostat, 2011; Hrubá, 2007; Oskarsdottir, 2017; UZIS ČR, 2012). The ELSPAC study provides results where out of $40 \%$ of women who smoked before conceiving, $20 \%$ kept smoking at the beginning of their pregnancy and $7 \%$ still smoked after giving birth. The lowest percentage of women smokers was found in Iceland. $12.2 \%$ of women were still smokers while attending their first prenatal counseling, $6.9 \%$ quit smoking in an early phase of pregnancy, and $5.3 \%$ of women were smokers during the whole pregnancy (Heppner et al., 2011; La Torre, 2013). Women with high levels of cotinine, claiming not to be a smoker, are very alike in their characteristics and prenatal results with women who smoke. Low reporting levels on smoking are most likely the result of a stigmatization of women smokers (Wigginton and Lee, 2013). A high-risk group of women, who are more frequent smokers during pregnancy, was consistentlydescribed: younger women with low social status, lower education level acquired, insufficient prenatal care, multiparous, with low social support, without a life partner or with a life partner who is a smoker. Women who experience stress, life trauma, and feel insufficiently loved (women with limited access to physiological sources of dopamine - sources acceptable by society) are at a higher risk of using maladaptive sources of dopamine. In primiparous women, lower counts of cigarettes smoked and a reduced urge to smoke were found (Filion et al., 2011; Männistö et al., 2016; Schneider and Schütz, 2008).

Within our sample, almost half of the respondents stated in their medical history that they were either an active or passive smoker. One third of the women quit smoking before or during pregnancy. Almost one fourth of fetuses from the sample of surveyed women were exposed to smoke either passively or actively for various time periods. This is in spite of the fact that most of the women were aware of the negative influence of smoking during pregnancy both on the mother and on the child. One third of the women had a record of smoking in their medical history and concurrently those women gave birth to a newborn with low birth weight. The incidence of smoking in women and their presence in a smoky environment was inversely proportional to age and level of education, and directly proportional to smoking within their family medical history. Smoking was less frequent during pregnancy in women who attended long-term prenatal courses.

Health behavior during pregnancy and perinatal results are influenced by psychosocial factors, which should be assessed during prenatal care at the latest. Women experiencing stress, depression and multiparous women more often show unhealthy habits. Women with a lower education level experience issues with looking up, processing and utilizing information that leads to health literacy. On the contrary, women with increasing level of education tend to behave in a healthier manner and their life quality increases. Essential is the prevalence of smokers among health practitioners, who are in general perceived as lifestyle role models (Bakker et al., 2005; Duckworth and Chertlock, 2012; Moshki et al., 2018; Von Kohorn et al., 2012).

As in various other studies, the health literacy of women in our sample was determined by their social level. Healthier behavior and lower incidence of risk factors were directly proportional to the level of education and pregnancy and parenthood preparation in prenatal courses. Pregnancy and parenthood preparation was more often represented in our sample in primiparous women and women with higher education level. Contact and consultations with a midwife during a prenatal course had a positive effect on several parameters, e.g., smok- 
ing, stress management, preparedness for delivery, etc. The influence was especially positive on the awareness and habits of women with lower education level, who unfortunately do not attend courses (particularly long-term courses) very often (Wilhelmová and Hrubá, 2014a).

The negative influences of insufficient literacy in women who are heavy smokers are higher numbers of miscarriages and unwanted pregnancies terminated by abortion. The level of cotinine in mothers correlates with the birth weight of newborns. There exists a specific high-risk group of women, composed of young women with unwanted pregnancies, who smoke, drink alcohol and use illegal drugs. A relationship between smoking and experiencing stress during pregnancy was also confirmed (Bottorff et al., 2014; Goodwin et al., 2017; Händel et al., 2009).

Our survey did not confirm a relationship between smoking and a miscarriage within medical history (the women classified themselves as light smokers). However, a significantly higher count of women smokers with pregnancies that were ended by an abortion was found. Women who stated they were smokers before conceiving and women who stated they were passive smokers during pregnancy were more likely to give birth to a newborn with lower birth weight. Consequently, women who were smokers were also more likely to drink alcohol and experience stress throughout the pregnancy.

In terms of prenatal care, it is also necessary to take into account the fact that during regular prenatal consultations the gynecologist does not usually have enough time to focus on interventions, especially those that are preventative. Subsequently, this sometimes results in a misinterpretation of facts, e.g., misinformation about the risks of withdrawal symptoms after one quits smoking, which exceed the benefits of abstinence (Filion et al., 2011; Janatová et al., 2008; Wilhelmová and Hrubá, 2014b). Based on the above mentioned factors, it shows that a possible solution for a timely prevention and the ability to catch all cases of women with high-risk behavior, the preventative work of midwives, both in cooperation with a gynecologist and their autonomous work in a community, should take place. The advantage of working in a clinic with a gynecologist would be the possibility to catch such cases before conception. The advantages of working in a community would be the possibility to catch cases of women smoking at home in the prenatal phase. Also, after delivery it would be possible to support women who quit smoking during pregnancy, so that adequate sources of dopamine could be provided in order to prevent a return to the smoking habit (Albrecht et al., 2011; Širvinskienè et al., 2016). In order to be successful with adequate substitutional interventions, a positive social interaction and knowledge of a key behavior-controlling factor that increases happiness (dopamine spillage), is essential. It is involved in both risky addictive activities and all supportive "addictive" activities that reduce the risk of smoking. This approach is applicable to long-term contact with women during prenatal and postnatal visits, where interventions are provided with the consent and active involvement of a woman. Preventive measures are needed in both primiparous and multiparous women. However, the expected effect can only be achieved on a full-scale basis with the support of legal and bureaucratic measures (Heppner et al., 2011; Jones et al., 2011; Tough et al., 2006).

The risk behavior of parents during preconception and prenatal phase plays a role in the postnatal etiology of various health disorders and the development of an individual. Thus it is necessary to restructure the current prenatal care model towards the optimal reproductive health of both women and men by improving their health literacy.

\section{Strengths and weaknesses of the study}

The strength of our survey is in its sample representativeness (with respect to age, parity in women, method of delivery and date of delivery). Concurrently, the size of the evaluated sample was also satisfactory, so that descriptive statistics provided us with results that sufficiently described the situation in our field of focus. At the same time, it was not possible to ensure $100 \%$ representativeness of our sample with respect to the education level acquired by the women. The most probable reason for this inadequacy was the disinterest of participation in the questionnaire survey by women with the lowest level of education. A certain level of weakness of the study could be represented by the social disparity between women who attended the prenatal courses and women who did not. In addition, the content of each prenatal course and the qualification level of the lecturers were not available. Another restriction of the study could be the quantitative survey design, which did not allow for a deeper understanding of the inner relations and origins of the discovered facts.

\section{Conclusions}

Despite the fact that there is quite a high level of awareness about the risks of smoking during pregnancy, a certain group of women still do not give up the habit. Younger women with a low level of education and multiparous women represent a group of women with the highest risk factor; therefore, these are women with a low level of awareness and higher incidence of high-risk behavior. In relation to smoking in women, significant determinants are shown to be; the level of education acquired, prenatal course attendance, and the presence of a smoking habit in their family history. It is essential to focus on the high-risk group of women, but also on the health care providers who provide prenatal care. Although most women go to their regular prenatal visits at the gynecologist, the number of women who smoke during pregnancy is evidence that our current model of prenatal care is still particularly lacking in terms of utilizing preventive intervention. Such intervention should result in improved health literacy in women with highrisk behavior.

\section{Conflict of interests}

The authors have no conflict of interest to declare. 


\section{Vybrané ukazatele vztahující se k výskytu kouření českých žen v těhotenství}

\section{Souhrn}

Úvod: Rizikové chování budoucích rodičů v podobě kouření již před početím a zejména pak prenatálně hraje významnou roli v etiologii různých abnormalit vývoje a poruch zdraví dítěte. Ty se mohou projevit okamžitě, a následně i s dlouhodobou latencí. Na chování budoucích matek mají dopad znalosti, které tvoří základ pro každodenní návyky žen. Kouření žen v těhotenství podmiňují faktory psychosociální. Výskyt tohoto rizikového chování může být pozitivně ovlivněn poskytovateli péče v rámci prenatálních poraden či kurzů; v optimálním případě již prekoncepčně.

Cíl: Záměrem práce bylo identifikovat faktory významně ovlivňující kouření českých žen ve vztahu k těhotenství a popsat nežádoucí jevy, které se v návaznosti na tento návyk u žen objevují.

Metodologie: Byla použita dotazníková metoda u žen po porodu ve vybraných lůžkových zdravotnických zařízeních Čech a Moravy a hodnocení některých antropometrických parametrů žen a novorozencủ. Statistická analýza byla provedena pomocí Pearsonova testu $\chi^{2}$ (chi-square) pro testování četnosti a testu Anova (analýza rozptylu) pro vícenásobné testování středních hodnot na hladině významnosti 0,05 .

Výsledky: Bylo zjištěno, že i přes relativně dobrou informovanost je v populaci budoucích matek kuřáctví rozšířeným návykem a souvisí zejména se stupněm dosaženého vzdělání žen a kouřením v původní rodině ženy. Některé ženy (30 \%) přestávají kouřit během období př́ípravy na těhotenství nebo až v jeho průběhu. Určitá část žen (10 \%) se svého návyku (aktivně či pasivně) nevzdává ani přes informovanost o riziku, které tento návyk přináší jak pro zdraví ženy, tak dítěte.

Závěr: Je zřejmé, že prevence a eliminace rizikového chování těhotných žen, v našem případě kouření, vykazuje stále značné rezervy. Důležitou součástí účelné prevence poškození plodu a budoucího vývoje dítěte nejen v rámci prenatální péče je zdravotní gramotnost, která může být zlepšena prostřednictvím prenatálních kurzů a poraden vedených porodní asistentkou.

Klíčová slova: faktory vlivu; kouření; prenatální kurzy; rizika; těhotenství; zdravotní gramotnost

\section{References}

1. Albrecht S, Kelly-Thomas K, Osborne JW, Ogbagaber S (2011). The SUCCESS program for smoking cessation for pregnant women. J Obstet Gynecol Neonatal Nurs 40(5): 520-531. DOI: 10.1111/j.1552-6909.2011.01280.x.

2. Ashford KB, Hahn E, Hall L, Rayens MK, Noland M, Ferguson JE (2010). The effects of prenatal secondhand smoke exposure on preterm birth and neonatal outcomes. J Obstet Gynecol Neonatal Nurs 39(5): 525-535. DOI: 10.1111/j.15526909.2010.01169.x.

3. Bakker MJ, de Vries H, Mullen PD, Kok G (2005). Predictors of perceiving smoking cessation counselling as a midwife's role: a survey of Dutch midwives. Eur J Public Health 15(1): 39-42. DOI: 10.1093/eurpub/cki109.

4. Barker DJ (2001). Fetal and infant origins of adult disease. Monatsschr Kinderheilkd 149 (Suppl. 1.): S2-S6. DOI: 10.1007/ s001120170002.

5. Berglund A (1999). Consequences of programme changes in antenatal care. Doctoral thesis. Comprehensive summaries of Uppsala dissertations from the Faculty of Medicine, vol. 888.

6. Bottorff JL, Poole N, Kelly MT, Greaves L, Marcellus L, Jung M (2014). Tobacco and alcohol use in the context of adolescent pregnancy and postpartum: a scoping review of the literature. Health Soc Care Commun 22(6): 561-574. DOI: 10.1111/ hsc.12091.

7. Duckworth AL, Chertlock IR (2012). Review of perinatal partner-focused smoking cessation interventions. MCN Am J Matern Child Nurs 37(3): 174-181. DOI: 10.1097/ NMC.0b013e31824921b4.

8. Ebert L, Van der Riet P, Fahy K (2009). What do midwives need to understand/know about smoking in pregnancy? Women Birth 22(1): 35-40. DOI: 10.1016/j.wombi.2008.11.001.

9. Eurostat Statistics Database (2011). Zpráva OECD a Evropské komise o zdraví v Evropě. Praha: ÚZIS ČR. [online] [cit. 201801-30]. Available from: http://www.uzis.cz/rychle-informace/ zprava-oecd-evropske-komise-zdravi-evrope

10. Filion KB, Abenhaim HA, Mottillo S, Joseph L, Gervais A, O'Loughlin J, et al. (2011). The effect of smoking cessation counselling in pregnant women: a meta-analysis of randomised controlled trials. BJOG 118(12): 1422-1128. DOI: 10.1111/j.1471-0528.2011.03065.x.

11. Gollwitzer ES, Marsland BJ (2015). Impact of early-life exposures on immune maturation and swusceotibility to Disease. Trends Imunol 36(11): 684-696. DOI: 10.1016/j. it.2015.09.009.

12. Goodwin RD, Cheslack-Postava K, Nelson DB, Smith PH, Hasin DS, Janevic T, et al. (2017). Serious psychological distress and smoking during pregnancy in the United States: 20082014. Nicotine Tob Res 19(5): 605-614. DOI: $10.1093 / \mathrm{ntr} /$ ntw323.

13. Hackshaw A, Rodeck C, Boniface S (2011). Maternal smoking in pregnancy and birth defects: a systematic review based on 173687 malformed cases and 11.7 million controls. Hum Reprod Update 17(5): 589-604.

14. Händel G, Hannöver W, Röske K, Thyrian JR, Rumpf HJ, Fusch C, et al. (2009). Intention to change smoking in pregnant and postpartum women according to number of pregnancies. Eur J Public Health 19(2): 218-221. DOI: 10.1093/eurpub/ ckn133.

15. Harville EW, Boynton-Jarrett R, Power C, Hyppönen E (2010). Childhood hardship, maternal smoking, and birth outcomes: a prospective cohort study. Arch Pediatr Adolesc Med 164(6) 533-539. DOI: 10.1001/archpediatrics.2010.61.

16. Heppner WL, Ji L, Reitzel LR, Castro Y, Correa-Fernandez V, Vidrine JI, et al. (2011). The role of prepartum motivation in the maintenance of postpartum smoking abstinence. Health Psychol 30(6): 736-745. DOI: 10.1037/a0025132.

17. Holčík J (2010). Systém péče o zdraví a zdravotní gramotnost. Brno: Masarykova univerzita.

18. Hrubá D (2007). Proč nekouřit v těhotenství - nové poznatky o účincích nikotinu. Prakt Gyn 11(3): 132-134.

19. Hrubá D (2011). Riziko kouření v těhotenství se stále podceňuje: tolerovat kouření v těhotenství je neodborné a neetické. Praktická gynekologie 15(1): 34-39.

20. Hrubá D, Kukla L, Okrajek P, Šikolová V (2013). Vliv perikoncepční a prenatální expozice kouření na mužskou reprodukci: poměr pohlaví a nástup puberty. Československá pediatrie 68(5): 283-292.

21. Hrubá D, Žaloudíková I (2009). Vliv rodiny na účinnost protikuřáckých výchovných programů. In: Řehulka E (Ed.). 
School and Health 21. Brno: Masarykova univerzita, pp. 197201.

22. Iams JD, Romeo R, Culhane JF, Goldenberg RL (2008). Primary, secondary, and tertiary interventions to reduce the morbidity and mortality of preterm birth. Lancet 371(9607): 164-175. DOI: 10.1016/S0140-6736(08)60108-7.

23. Janatová $H$, Štundlová D, Skývová M, Uličná E (2008). Komplexní intervence v těhotenství. Hygiena 53(Suppl. 1): 48-51.

24. Jones SC, Telenta J, Shorten A, Johnson K (2011). Midwives and pregnant women talk about alcohol: what advice do we give and what do they receive? Midwifery 27(4): 489-496. DOI: 10.1016/j.midw.2010.03.009.

25. Kataoka MC, Carvalheira APP, Ferrari AP, Malta MB (2018). Smoking during pregnancy and harm reduction in birth weight: a cross-sectional study. BMC Pregnancy Childbirth 18(1): 67. DOI: 10.1186/s12884-018-1694-4.

26. Kukla L, Hrubá D, Tyrlík M (2000). Kouření a stres: výsledky studie ELSPAC. Česká a slovenská psychiatrie 96(6): 316-321.

27. La Torre G (2013). Smoking prevention and cessation. Roma: Springer.

28. Leonardi-Bee J, Smyth A, Britton J, Coleman T (2008). Environmental tobacco smoke and fetal health: systematic review and meta-analysis. Arch Dis Child Fetal Neonatal Ed 93(5): F351-F361. DOI: 10.1136/adc.2007.133553.

29. Lillycrop KA, Burdge GC (2012). Epigenetic mechanisms linking early nutrition to long-term health. Best Pract Res Clin Endocrinol Metab 26(5): 667-676. DOI: 10.1016/j. beem.2012.03.009.

30. Lipton BH (2011). Biologie víry: Jak uvolnit sílu vědomí, hmoty a zázraků. Olomouc: Anag.

31. Malik S, Cleves MA, Honein MA, Romitti PA, Botto LD, Yang S, et al. (2008). Maternal smoking and congenital heart defects. Pediatrics 121(4): 810-816. DOI: 10.1542/peds.2007-1519.

32. Männistö T, Bloigu A, Heino A, Gissler M, Surcel HM (2016). Changes in objectively measured smoking in pregnancy by time and legislative changes in Finland: a retrospective cohort study. BMJ Open 6: e013296. DOI: 10.1136/bmjopen-2016-013296.

33. Moshki M, Mirzania M, Kharazmi A (2018). The relationship of health literacy to quality life and demographic factors in pregnant women. Journal of Health Literacy 2(4): 203-215.

34. Mulder EJ, Robles de Medina PG, Huizink AC, Van den Bergh BR, Buitelaar JK, Visser GH (2002). Prenatal maternal stress: effects on pregnancy and the (unborn) child. Early Hum Dev 70(1-2): 3-14. DOI: 10.1016/S0378-3782(02)00075-0.

35. Oskarsdottir GN, Sigurdsson H, Gudmundsson KG (2017). Smoking during pregnancy: A populationbased study. Scand J Public Health 45(1): 10-15. DOI: $10.1177 / 1403494816676034$.

36. Patterson AJ, Chen M, Xue Q, Xiao D, Zhang L (2010). Chronic prenatal hypoxia induces epigenetic programming of $\mathrm{PKC} \varepsilon$ gene repression in rat hearts. Circ Res 107(3): 365-373. DOI: 10.1161/CIRCRESAHA.110.221259.
37. Paul K, Boutain D, Agnew K, Thomas J, Hitti J (2008). The relationship between racial identity income, stress and $C$-reactive protein among parous women: implications for preterm birth disparity research. J Natl Med Assoc 100(5): 540-546. DOI: 10.1016/S0027-9684(15)31300-6.

38. Pender NJ (2011). The Health Promotion Model Manual. [online] [cit. 2013-01-08]. Available from: http://deepblue. lib.umich.edu/bitstream/handle/2027.42/85350/HEALTH_ PROMOTION_MANUAL_Rev_5-2011.pdf?sequence=1

39. Schneider S, Schütz J (2008). Who smokes during pregnancy? A systematic literature review of population-based surveys conducted in developed countries between 1997 and 2006. Eur J Contracept Reprod Health Care 13(2):138-147. DOI: 10.1080/13625180802027993.

40. Šípek A, Gregor V, Horáček J, Šípek A, Langhammer P (2012). Vývoj a změny incidencí vrozených vad u narozených dětí v České republice. Čes Gynek 77(5): 424-436.

41. Širvinskienė G, Žemaitienè N, Jusienè R, Šmigelskas K, Veryga A, Markūnienė E (2016). Smoking during pregnancy in association with maternal emotional well-being. Medicina (Kaunas) 52(2): 132-138. DOI: 10.1016/j.medici.2016.02.003.

42. Suzuki K, Tanaka T, Kondo N, Minai J, Sato M, Yamagata Z (2008). Is maternal smoking during early pregnancy a risk factor for all low birth weight infants? J Epidemiol 18(3): 89-96. DOI: 10.2188/jea.JE2007415.

43. Tough SC, Johnston DW, Siever JE, Jorgenson G, Slocombe L, Lane C, Clarke M (2006). Does supplementary prenatal nursing and home visitation support improve resource use in a universal health care system? A randomized controlled trial in Canada. Birth 33(3): 183-194. DOI: 10.1111/j.1523536X.2006.00103.x.

44. ÚZIS ČR (2012). Rodička a novorozenec. Praha: ÚZIS ČR.

45. Von Kohorn I, Nguyen SN, Schulman-Green D, Colson ER (2012). A qualitative study of postpartum mothers' intention to smoke. Birth 39(1): 65-69. DOI: 10.1111/j.1523536X.2011.00514.x.

46. Welberg LA, Seckl JR (2001). Prenatal stress, glucocorticoids and the programming of the brain. J Neuroendocrinol 13(2): 113-128.

47. WHO (2018). WHO recommendations on antenatal care for a positive pregnancy experience. Geneva: World Health Organization.

48. Wigginton B, Lee C (2013). Stigma and hostility towards pregnant smokers: does individuating information reduce the effect? Psychol Health 28(8): 862-873. DOI: 10.1080/08870446.2012.762101.

49. Wilhelmová R, Hrubá D (2014a). Které ženy se připravují na své těhotenství a mateřství? Hygiena 59(4): 162-166. DOI: 10.21101/hygiena.a1267.

50. Wilhelmová R, Hrubá D (2014b). Odvykání kouření v těhotenství. Prakt Gyn 18(2): 134-139. 